\title{
Review jurnal: Kajian tentang keajaiban dan manfaat urine unta
}

\author{
Afifah Rosyidah*, Lukman Atmaja \\ Departemen Kimia, Fakultas Sains dan Analitika Data, Institut Teknologi Sepuluh Nopember, \\ Surabaya, 60111, Indonesia.
}

\begin{abstract}
ABSTRAK
Sebagai ciptaan Allah SWT, unta merupakan binatang yang mempunyai keistimewaan luar biasa. Kajian ini membahas tentang urine unta yang didasarkan atas studi nalar hadis serta pendekatan medis. Sedangkan rumusan masalah serta tujuan utama kajian ini adalah guna mendapatkan pemahaman yang sahih tentang kedudukan hadis-hadis dalam mengkaji tentang urine unta, menganalisis pendapat para ulama tentang pengobatan menggunakan urine unta berdasarkan hadis Rasulullah SAW, serta mendeskripsikan manfaat urine unta dalam bidang medis. Beberapa jurnal menyatakan manfaat urine unta yang luar biasa untuk pengobatan. Selain susu, urine unta mempunyai efek positif yang tidak kalah penting, yaitu untuk penyembuhan berbagai macam penyakit, terutama penyakit kanker dan berbagai penyakit yang disebabkan oleh kuman patogen (mikroba penyebab berbagai macam penyakit). Bebarapa ulama dan ahli fikih serta hadis-hadis yang kuat sanadnya menyatakan tidak najis dan diperbolehkan mengonsumsi urine unta. Meski demikian, ada juga yang menyatakan bahwa urine unta najis.
\end{abstract}

Kata kunci: Manfaat, Obat, Urine unta.

C. 2017 Pusat Kajian Halal ITS. All rights reserved.

\section{Pendahuluan}

Dalam Q.S. Al-Ghaasyiyah ayat 17, Allah SWT mengajak kita untuk memberikan perhatian khusus kepada mahkluk cantik dan unik bernama unta.

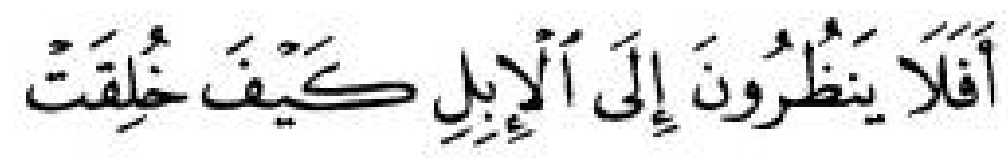

"Maka apakah mereka tidak memperhatikan UNTA, bagaimana ia diciptakan." (Q.S. AlGhaasyiyah: 17).

Unta merupakan binatang luar biasa yang mempunyai tinggi tubuh 1,8-3 meter, mampu meminum air $135 \mathrm{~L}$ sekali minum dan dapat bertahan tanpa makan dan minum selama 8 hari. Unta mempunyai punuk yang mampu menyimpan lemak guna mendinginkan tubuhnya dan sungguh luar biasa lemak ini dapat diubah menjadi makanan atau air, subhanallah. Unta

\footnotetext{
* Corresponding author. Tel: 081555617157; Fax: -.

Email address: afifah@chem.its.ac.id
} 
mampu melakukan perjalanan panjang sambil mengangkut beban $170-270 \mathrm{~kg}$. Selain itu, susu unta mempunyai keunggulan [1]:

- Kandungan laktosanya lebih rendah daripada susu kambing.

- Kandungan mineralnya ( $\mathrm{Na}, \mathrm{K}, \mathrm{Fe}, \mathrm{Cu}, \mathrm{Mg}, \mathrm{Mn}$, dan $\mathrm{Zn}$ ) lebih tinggi daripada susu sapi.

- Kandungan kolesterolnya lebih rendah dari susu sapi/kambing.

- Kandungan vitamin C 3x lebih tinggi dan zat besi 10x lebih tinggi daripada susu sapi dan kambing.

- Kaya akan berbagai asam lemak tak jenuh, enzim, dan vitamin B.

- Kandungan protein dan lemaknya lebih tinggi daripada susu sapi.

- Dapat dipakai untuk terapi/pengobatan problem pada limpa, juga penyakit tuberculosis, asma, anemia, dan lain-lain.

- Manfaat medis, seperti: antibakteri, antivirus, antidiabetes, antialergi, antikanker, antipenuaan (ageing), antihiperglikemik.

Ada yang berpendapat bahwa urine unta itu menjijikkan, namun ada pula yang berkeyakinan bahwa secara medis ada unsur obat pada urine unta tersebut. Lalu bagaimana sesungguhnya Islam memandang urine unta ini, apakah najis atau tidak, halal atau tidak? Maka akan direview dalam ulasan berikut.

\section{Review jurnal dan diskusi}

Metoda yang digunakan dalam kajian ini menggunakan pendekatan dari berbagai pendapat ulama dan ahli fikih, serta beberapa hadis yang kuat sanadnya. Hukum air kencing binatang yang halal dagingnya (unta termasuk dalam kelompok ini), najis atau tidak. Ada beberapa pendapat dari para ulama:

\section{a. Pendapat pertama: TIDAK NAJIS}

Para ulama yang bermadzhab Malikiyah dan Hanabilah, serta sebagian dari Madzhab Syafi'iyah (Ibnu Mundzir, Ibnu Hibban, Ibnu Huzaimah, Abu Sa'id al Isthihri, Royyani, dan lain-lain) berpendapat bahwa air kencing binatang yang dagingnya halal adalah tidak najis.

Dalilnya adalah sebagai berikut:

"Dari Anas bin Malik, beliau berkata, "Sebelum masjid dibangun, Nabi SAW salat di kandang kambing." (HR. Bukhari).

"Dari Anas berkata, "Beberapa orang dari 'Ukl atau 'Urainah datang ke Madinah, namun mereka tidak tahan dengan iklim Madinah hingga mereka pun sakit. Beliau lalu memerintahkan mereka untuk mendatangi unta dan meminum air kencing dan susunya. Maka mereka pun berangkat menuju kandang unta (zakat), ketika telah sembuh, mereka membunuh penggembala unta Nabi SAW dan membawa unta-untanya. Kemudian berita itu pun sampai kepada Nabi SAW menjelang siang. Maka beliau mengutus rombongan untuk mengikuti jejak mereka, ketika matahari telah tinggi, utusan beliau datang dengan membawa mereka. Beliau lalu memerintahkan agar mereka dihukum, maka tangan dan 
kaki mereka dipotong, mata mereka dicongkel, lalu mereka dibuang ke padang pasir yang panas. Mereka minta minum namun tidak diberi." (HR. Bukhari dan Muslim).

"Dari Jabir bin Samurah, bahwa seorang laki-laki bertanya kepada Rasulullah SAW, "Apakah kami harus berwudhu karena makan daging kambing?" Beliau menjawab, "Jika kamu berkehendak maka berwudhulah, dan jika kamu tidak berkehendak maka janganlah kamu berwudhu." Dia bertanya lagi, "Apakah harus berwudhu disebabkan (makan) daging unta?" Beliau menjawab, "Ya. Berwudhulah disebabkan (makan) daging unta." Dia bertanya, "Apakah aku boleh salat di kandang kambing?" Beliau menjawab, "Ya boleh." Dia bertanya, "Apakah aku boleh salat di kandang unta?" Beliau menjawab, "Tidak." (HR. Muslim).

Ketiga hadis di atas jelas sekali menunjukkan bahwa air kencing binatang yang dagingnya halal itu adalah TIDAK NAJIS.

b. Pendapat kedua: NAJIS

Para ulama yang bermadzhab Hanafiyah dan Syafi'iyah berpendapat bahwa air kencing binatang yang dagingnya (termasuk unta) halal adalah najis.

Qadhi Husain (salah satu ulama Syafi'iyah) berkata:

"Menurut madzhab kami, apa yang keluar darinya seperti air kencing atau kotoran adalah najis, baik itu dari binatang yang dagingnya halal maupun yang dagingnya haram, baik itu kotoran burung, maupun bukan burung."

Dalil-dalil yang dipakai adalah dalil keumuman kenajisan air kencing sebagai berikut:

"Dari Ibnu 'Abbas, beliau berkata, "Rasulullah SAW lewat di dekat dua kuburan, lalu beliau bersabda: "Sesungguhnya keduanya sedang disiksa dan keduanya disiksa bukan karena dosa besar. Yang satu disiksa karena tidak bersuci setelah kencing, sementara yang satunya suka mengadu domba." Kemudian beliau mengambil sebatang dahan kurma yang masih basah, beliau lalu membelahnya menjadi dua bagian kemudian menancapkannya pada masing-masing kuburan tersebut. Para sahabat pun bertanya,"Wahai Rasulullah, kenapa engkau melakukan ini?" Beliau menjawab,"Semoga siksa keduanya diringankan selama batang pohon ini basah." (HR. Bukhari dan Muslim).

"Abu Hurairah berkata,"Seorang Arab badui berdiri dan kencing di Masjid, lalu orang-orang ingin mengusirnya. Maka Nabi SAW pun bersabda kepada mereka,"Biarkanlah dia dan siramlah bekas kencingnya dengan setimba air atau dengan seember air. Sesungguhnya kalian diutus untuk memberi kemudahan dan tidak diutus untuk membuat kesulitan." (HR. Bukhari).

"Dari Anas, beliau berkata, Rasulullah SAW bersabda,"Bersihkan dari air kencing, karena sesungguhnya kebanyakan azab kubur itu dari air kencing (yang tidak dibersihkan)." (HR. Daruquthni). 
Dapat dilihat dari kedua pendapat ulama di atas bahwa yang lebih kuat dalilnya adalah pendapat yang mengatakan bahwa air kencing binatang yang dagingnya halal adalah TIDAK NAJIS alias SUCI.

Muncul pertanyaan berikutnya, apakah berobat dengan minum air kencing unta: halal atau haram?

Apabila ditelaah, ternyata para ulama SEPAKAT MEMPERBOLEHKAN berobat dengan minum air kencing unta. Pertimbangannya adalah sebagai berikut:

Pertama, bagi kelompok yang tidak menajiskan air kencing unta, maka tentu tidak masalah meminum cairan yang hukumnya suci (tidak najis). Bagi kelompok yang menajiskannya, maka berobat dengan meminum air kencing unta adalah boleh karena adanya unsur darurat.

Khatib Syarbini mengatakan bahwa: "Adapun perintah Rasulullah SAW kepada Al 'Arayinin untuk meminum kencing unta tersebut tujuannya adalah untuk pengobatan. Dan pengobatan dengan sesuatu yang najis dibolehkan, jika memang yang suci tidak bisa menggantikannya."

Selanjutnya, dari Ibnu Abbas, bersabda Rasulullah SAW:

"Sesungguhnya dalam air kencing unta dan susunya bisa untuk mengobati sakit perut mereka (yang rusak pencernaannya)." (HR. Ahmad, Thabrani, dan Thohawi).

Kedua, banyak bukti ilmiah (uji laboratorium) yang menunjukkan bahwa air kencing unta memiliki efek pengobatan [2],[3],[4],[5],[6],[7],[8],[9],[10],[11]. Air kencing (urine) yang dicampur dengan susu unta terbukti bisa menyembuhkan berbagai penyakit, seperti: kanker, leukemia (kanker darah), hepatitis, serta diabetes. Air kencing unta juga dilaporkan dapat mengobati berbagai problem di perut, termasuk yang disebabkan oleh sakit pada organ hati.

Air kencing unta telah secara luas dipakai di Jazirah Arabia untuk mengobati penyakit kanker [4]. Secara in-vitro, air kencing unta ini terbukti mematikan sel-sel kanker manusia. Yang menarik, konsumsi $216 \mathrm{mg} / \mathrm{ml}$ air kencing unta yang telah dikeringkan dengan cara freezedrying terbukti mampu menghambat perkembangan sel kanker. Air kencing unta, baik unta dara, unta bunting, maupun unta yang sedang laktasi, mampu menghambat induksi ekspresi gen Cytochrome P450 1a1, sehingga pertumbuhan sel kanker manusia dapat terhambat [12]. Level penghambatan sel kanker yang paling tinggi ditunjukkan oleh air kencing unta dara (unta betina yang belum pernah dikawinkan), baru kemudian diikuti oleh air kencing unta yang sedang menyusui (masa laktasi) dan air kencing unta betina bunting [13].

Partikel nano pada air kencing unta terbukti mampu melawan sel kanker dengan cukup kuat. Air kencing unta mengandung senyawa bioaktif yang memiliki efek mematikan sel-sel yang berbahaya dan mampu menjaga populasi sel-sel yang sehat pada pasien kanker. Jenis penyakit kanker yang dapat diobati dengan air susu dan air kencing unta di antaranya 
adalah: kanker payudara, kanker darah, kanker perut, kanker usus besar, kanker paru-paru, serta tumor otak sekaligus sebagai antiinflamasi [2],[3],[4],[14]. Jamur mikotoksin dan berbagai jamur lain yang dapat merusak kerja hati dan ginjal manusia dapat dihambat pertumbuhannya dengan air kencing unta dalam konsentrasi tinggi [5]. Hasil penelitian tersebut selaras dengan publikasi Al-Awadi dan Al-Judaibi yang menunjukkan bahwa air kencing unta secara umum memiliki efek antibiotik alami [5],[8].

\section{Kesimpulan}

Pendapat serta uraian yang telah dinyatakan menunjukkan bahwa air kencing unta tidak najis dan memiliki efek positif untuk penyembuhan berbagai penyakit, terutama penyakit kanker dan berbagai penyakit yang disebabkan oleh kuman patogen (mikroba penyebab penyakit). Berobat dengan urine unta diperbolehkan, tapi tidak harus. Jika berkehendak, silakan. Jika tidak, juga tidak apa-apa. Rasulullah SAW tidak pernah mewajibkan berobat dengan urine unta.

\section{Referensi}

[1] Y. Shabo, R. Barzel, M. Margoulis, and R. Yagil, "Camel milk for food allergies in children," Immunology and Allergies. vol. 7, pp. 796-798, 2005.

[2] Z. Alghamdi and F. Khorshid, "Cytotoxicity of the urine of different camel breeds on the proliferation of lung cancer cells, A549," J. Nat. Sci. Res., vol. 2, pp. 9-16, 2012.

[3] N.B. Alitheen, and N.M.A.N.A. Rahman. "The growth inhibitory potential and antimetastatic effect of camel urine on breast cancer cells in vitro and in vivo," Integr. Cancer Ther., vol. 16, pp. 540-555, 2017.

[4] N. Al-Yousef, A. Gaafar, B. Al-Otaibi, I. Al-Jammaz, K. Al-Hussein, and A. Aboussekhra, "Camel urine components display anticancer properties in vitro." J. Ethnopharmacol., vol. 143, pp. 819-825, 2012.

[5] A.H.A. Al-Abdalall, "The inhibitory effect of camel's urine on mycotoxinsand fungal growth," Afr. J. Agric. Res., vol. 5, pp. 1331-1337, 2010.

[6] M.S. Mostafa and R.A. Dwedar, "Antimicrobial activity of camel's urine and its effect on multidrug resistant clinical bacterial and fungal isolates," Br. J. Pharm. Res., vol. 13, no. 4, pp. 1-6, 2016.

[7] B.E. Read, "Chemical constituents of camels's urine," J. Biol. Chem., vol. 64, pp. 615-617, 1925.

[8] A. Al-Awadi and A. Al-Judaibi, "Effects of heating and storage on the antifungal activity of Camel urine," J. Clin. Microbiol., vol. 3, pp. 6, 2014.

[9] S.H Alzahrani and A.A. Alharbi, "Antimicrobial activity of camel's urine on methicillinresistant Staphylococcus aureus isolated from clinical specimens," Science, vol. 23, pp. 251-268, 2011.

[10] M.M. Al-Bashan, "In vitro assessment of the antimicrobial activity and biochemical properties of camel's urine against some human pathogenic microbes," Middle-East J. Sci. Res., vol. 7, pp. 947-958, 2011.

[11] A. Alhaidar, A.G.M. Abdul Gader, and S.A. Mousa, "The antiplatelet activity of camel urine," J. Altern. Complement. Med., vol. 17, pp. 803-808, 2011. 
[12] A.A. Almehdara, N.A El-Bakyb, A.A Abdulqader and E.M. Redwan, "Immunogenicity comparison of lactoferrin purified from Saudi Arabia camel clans milk," Hum. Antibodies, vol. 27, pp. 85-90, 2019

[13] A.A. Abdulqader, A.A., M.A. El Gendy, H.M. Korashy, and A.O. El-Kadi, "Camel urine inhibits the cytochrome P450 1a1 gene expression through an AhR-dependent mechanism in Hepa 1c1c7 cell line," J. Ethnopharmacol., vol. 133, pp. 184-190, 2010.

[14] Z. Hu, X. Chang, Q. Pan, K. Gu, and P.N. Okechukwu, "Gastroprotective and ulcer healing effects of camel milk and urine in $\mathrm{HCl} / \mathrm{EtOH}$, non-steroidal anti-inflammatory drugs (Indomethacin), and water-restraint stress-induced ulcer in rats", Pharmacogn. Mag., vol. 13, pp. 559-565, 2017. 